\title{
The study of cognitive function in children with type 1 diabetes mellitus
}

\author{
$\mathrm{NI}$ Jia, XIN Ying* \\ From 7th APPES Biennial Scientific Meeting \\ Nusa Dua, Bali. 14-17 November 2012
}

\begin{abstract}
Aims
To determine if frequent exposures to hypoglycemia and hyperglycemia during early childhood lead to neurocognitive deficits, and explore the possible affected factors.
\end{abstract}

\section{Methods}

We Chosen 32 cases of children with type 1 diabetes mellitus. They were aged from 6-16 years. The duration of the disease was more than one year. We used Chinese Wechsler Intelligence Scale for measurement and analyzing cognitive function, and compared with age- and sex-matched healthy control subjects (control group). We explored the influence of glycosylated hemoglobin and hypoglycemia on cognitive function as well.

\section{Results}

The full intelligence quotient and the verbal intelligence quotient of diabetic group were lower than the control group. In the sub-tests, as words of knowledge, category, comprehension, arithmetic, vocabulary scale points of diabetic group was significantly lower than that of control group. The verbal comprehension factor and memory/attention factor of the two groups had significantly difference. Glycosylated hemoglobin of diabetic children had a linear regression relationship with total IQ and verbal IQ.

\section{Conclusion}

Diabetes mellitus had effects on children's verbal intelligence quotient and attention, which affected the full intelligence quotient. Glycosylated hemoglobin was the independent risk factor to the full intelligence quotient. Larger cross-sectional and longitudinal studies of

\footnotetext{
Department of Pediatrics, Shengjing Hospital, China Medical University,
} Shenyang, Liaoning 100004, China

(C) 2013 Jia and Ying; licensee BioMed Central Ltd. This is an Open Access article distributed under the terms of the Creative Commons Attribution License (http://creativecommons.org/licenses/by/2.0), which permits unrestricted use, distribution, and reproduction in any medium, provided the original work is properly cited.
doi:10.1186/1687-9856-2013-S1-P34

Cite this article as: Jia and Ying: The study of cognitive function in children with type 1 diabetes mellitus. International Journal of Pediatric Endocrinology 2013 2013(Suppl 1):P34.
Submit your next manuscript to BioMed Central and take full advantage of:

- Convenient online submission

- Thorough peer review

- No space constraints or color figure charges

- Inclusion in PubMed, CAS, Scopus and Google Scholar

- Research which is freely available for redistribution
- Immediate publication on acceptance 